\title{
Evidence for Millennial-Scale Climate Change During Marine Isotope Stages 2 and 3 at Little Lake, Western Oregon, U.S.A.
}

\author{
Laurie D. Grigg ${ }^{1}$ and Cathy Whitlock \\ Department of Geography, University of Oregon, Eugene, Oregon 97403
}

and

Walter E. Dean

U.S. Geological Survey, MS 980 Federal Center, Denver, Colorado 80225

Received June 28, 2000; published online May 31, 2001

\begin{abstract}
Pollen and geochemical data from Little Lake, western Oregon, suggest several patterns of millennial-scale environmental change during marine isotope stage (MIS) 2 (14,100-27,600 cal yr B.P.) and the latter part of MIS $3(27,600-42,500$ cal yr B.P.). D uring MIS 3 , a series of transitions between warm- and cold-adapted taxa indicate that temperatures oscillated by ca. $2^{\circ}-4^{\circ} \mathrm{C}$ every $1000-3000 \mathrm{yr}$. $H$ ighs and lows in summer insolation during MIS 3 are generally associated with the warmest and coldest intervals. Warm periods at Little Lake correlate with warm sea-surface temperatures in the Santa Barbara Basin. Changes in the strength of the subtropical high and the jet stream may account for synchronous changes at the two sites. During MIS 2, shifts between mesic and xeric subalpine forests suggest changes in precipitation every $1000-3000 \mathrm{yr}$. Increases in Tsuga heterophylla pollen at 25,000 and 22,000 cal yr B.P. imply brief warmings. Minimum summer insolation and maximum global ice-volumes during MIS 2 correspond to cold and dry conditions. Fluctuations in precipitation at $\mathrm{L}$ ittle L ake do not correlate with changes in the Santa B arbara B asin and may be explained by variations in the strength of the glacial anticyclone and the position of the jet stream. $\odot 2001$ University of Washington.
\end{abstract}

Key Words: Pacific Northwest; pollen records; millennial-scale climate change; marine isotope stages 2 and 3; paleoecology.

\section{INTRODUCTION}

Millennial-scale climate changes are evident in paleoclimate records from the late Holocene to the early Pleistocene (Bond et al., 1997; Raymo et al., 1998). However, much of this research has focused on the last glacial period $(125,000-14,000 \mathrm{cal} \mathrm{yr}$ B.P.), which in many parts of the world is characterized by a series of abrupt and extreme climate oscillations. Recent studies suggest that some of these changes were global in extent and

\footnotetext{
${ }^{1}$ Current Address: Department of Geography, Dartmath College, Hanover, NH 03755. E-mail: Laurie.Davis-Grigg@ Dartmath.edu.
}

involved complex interactions between the atmosphere, oceans, biosphere, and cryosphere (see review by Alley, 1998). Despite these advances, questions remain about the origin and global occurrence of millennial-scale climate change.

In western North America, records from the Great Basin and the Pacific Northwest describe millennial-scale changes in pluvial lake levels, glacial extent, and vegetation during the last glacial period (Benson, 1999; Hicock et al., 1999; Lin et al., 1998; Whitlock and Grigg, 1999). In the Northeast Pacific, cores from the Santa Barbara Basin and the central California and southern Oregon margins show variations in sea-surface temperatures and oceanic circulation (Behl and Kennett, 1996; Gardner et al., 1997; Hendy and Kennett, 1999; Lund and Mix, 1998). Millennial-scale variations in these regions have primarily been associated with shifts in the position and strength of the Eastern Pacific subtropical high, the Aleutian low, and the jet stream. However, fluctuations in the ventilation of intermediate and deep water in the North Pacific indicate that changes in North Pacific oceanic circulation may also have been involved (Lund and Mix, 1998). In addition, there is evidence that millennialscale climate change in western North America may be partially regulated by orbital-scale controls, such as insolation and the size of the Laurentide ice sheet (Clark and Bartlein, 1995).

Vegetation changes in south-central Washington and glacial advances in southwestern British Columbia imply a series of climate oscillations that occurred ca. every 5000-8000 cal yr during the last glacial period in the Pacific Northwest (Hicock et al., 1999; Whitlock and Grigg, 1999). However, records from the Santa Barbara Basin and the Great Basin show a higher frequency of climate change (ca. every 1000-3000 cal yr; Benson, 1999; Lin et al., 1998). The absence of a higher frequency climate change in Pacific Northwest records may reflect a relatively coarse sampling resolution, or it may suggest different patterns of change for separate regions of western North America and the Northeast Pacific. A better understanding of millennial-scale climate change in the Pacific Northwest will 


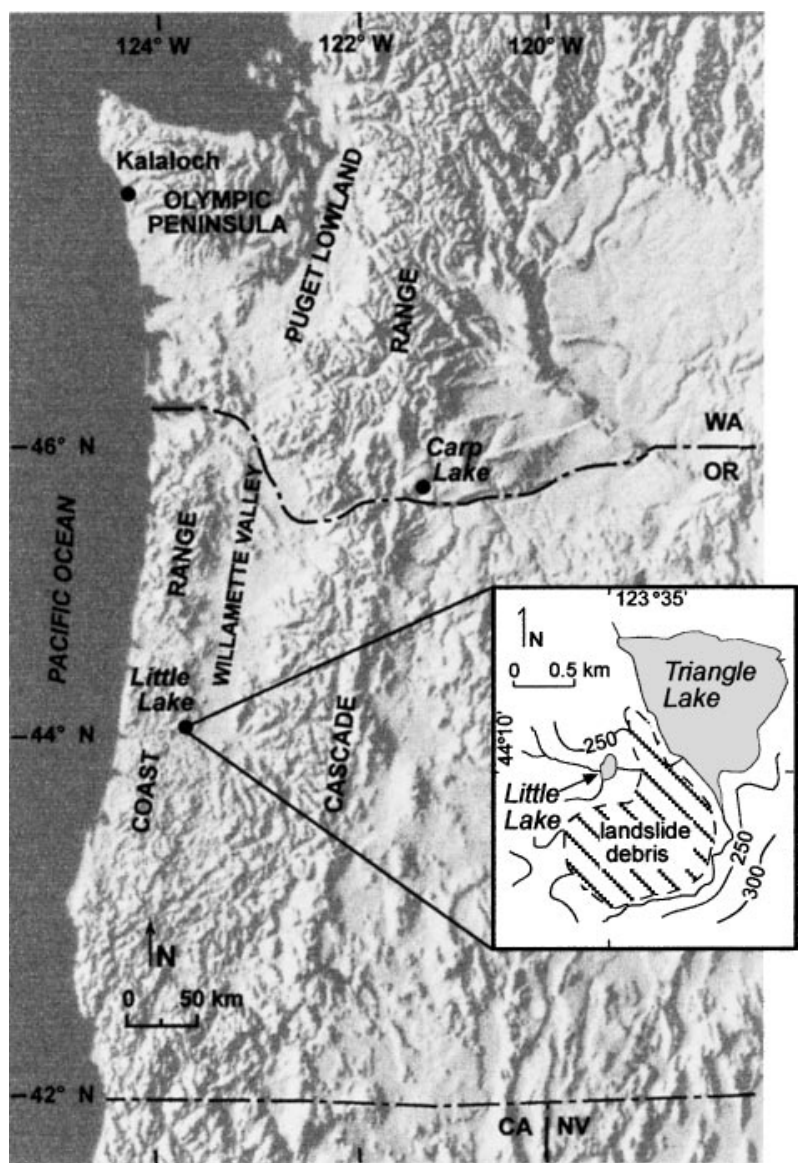

FIG. 1. Map and inset showing location and topography of Little Lake. Other sites mentioned in the text are also shown.

help identify the mechanisms responsible for these changes in western North America and the Northeast Pacific.

In this study, we present high-resolution palynological, lithologic, and geochemical data from Little Lake in the central Coast Range of Oregon (Fig. 1). This record extends from 42,500 to $27,600 \mathrm{cal}$ yr B.P. and corresponds to the latter part of marine isotope stage (MIS) 3 and MIS 2. We describe the character, timings, and frequency of climate changes at Little Lake and evaluate the influence of orbital-scale climate controls. This study also aims to establish some proximal causes for these changes by comparing the Little Lake record with a high-resolution record from the Santa Barbara Basin (Behl and Kennett, 1996). Similar patterns of climate change in these two regions would imply the occurrence of large-scale shifts in atmospheric circulation over the North Pacific during the last glacial period. Differences would suggest regional-scale changes or the greater influence of specific climate controls, such as a glacial anticyclone, on one region.

Little Lake $\left(44^{\circ} 10^{\prime} \mathrm{N}, 123^{\circ} 35^{\prime} \mathrm{W}, 217\right.$ m elevation), located $45 \mathrm{~km}$ east of the Pacific Ocean, was formed ca. 42,500 cal yr B.P. by a landslide (Fig. 1; Grigg and Whitlock, 1998; Long et al., 1998; Worona and Whitlock, 1995). At present, Little Lake lies within the Tsuga heterophylla zone (250-1000 m elevation), which is dominated by Pseudotsuga menziesii (Douglas-fir), T. heterophylla (western hemlock), Thuja plicata (western red cedar), and Alnus rubra (red alder) with minor amounts of Abies grandis (grand fir) and Pinus monticola (western white pine; Franklin and Dyrness, 1988). The climate of the Coast Range is characterized by mild, wet winters and warm, dry summers. Mid-latitude cyclones associated with the southward displacement of the jet stream result in 75-85\% of the annual precipitation occuring in the winter (Mock, 1996). The subtropical high and the jet stream shift northward in the summer, bringing warm, dry conditions to the Pacific Northwest.

\section{METHODS}

A 17.25-m-long core was collected with a 5-cm-diameter piston sampler (Wright et al., 1983) from the fen surrounding Little Lake. In the laboratory, cores were sliced longitudinally, and the lithology was described. From 10.56 to $17.22 \mathrm{~m}$ depth, samples of $1 \mathrm{~cm}^{3}$ were taken for pollen analysis every 4 to $6 \mathrm{~cm}$. From 11.48 to $17.22 \mathrm{~m}$ depth, samples of ca. $6-10 \mathrm{~cm}^{3}$ of sediment were taken every 4 to $8 \mathrm{~cm}$ and analyzed for carbon content and major and trace elements. The remaining core was used for magnetic susceptibility measurements, macrofossil analysis, and radiocarbon dating.

Pollen samples were processed using standard procedures (Cwynar et al., 1979; Faegri et al., 1989). A known amount of Lycopodium spores was added to each sample to calculate the concentration of pollen (grains $/ \mathrm{cm}^{3}$ ). Pollen was examined at magnifications of $400 \times$ and $1000 \times$ and identified using modern pollen collections and published atlases (McAndrews et al., 1973; Moore and Webb, 1978). Pinus (pine) pollen grains were identified as haploxylon-type and diploxylon-type when the distal membrane of the pollen grain was preserved. Those grains without an intact distal membrane were classified as "undifferentiated." Pinus-types, Abies (fir), Picea (spruce), and Cupressaceae (juniper family) could not be identified to the species level without the presence of macrofossils. However, modern ecological associations and phytogeography were used to determine which species were the most likely contributors. Pollen percentages were calculated based on the sum of terrestrial pollen and spores. Pollen accumulation rates (PAR; grains $/ \mathrm{cm}^{2} / \mathrm{yr}$ ), pollen concentrations (grains $/ \mathrm{cm}^{3}$ ), and deposition times $(\mathrm{yr} / \mathrm{cm})$ were calculated using the TILIA program (Grimm, 1988). Pollen zones from Worona and Whitlock (1995) were further divided into subzones based on the results of a constrained cluster analysis (CONISS; Grimm, 1988).

Measurements of sediment magnetism indicate changes in the input or preservation of minerogenic clasts to a lake and imply variations in the allochthonous component or anoxic-vs.-oxic conditions, which can be used to infer environmental changes (Thompson and Oldfield, 1986). Magnetic susceptibility was measured every $2 \mathrm{~cm}$ on $6-\mathrm{cm}^{3}$ subsamples of sediment using a cup-coil magnetic susceptibility instrument. A software program, Magsus.pas (David Adam and Sarah Shafer, personal 
communication, 1993) recorded and averaged four, 4-s readings of each sample. The results were converted to concentration values of electromagnetic units (emu/cm3). Total carbon (C) was measured by combusting untreated samples of dried and crushed sediment at $960^{\circ} \mathrm{C}$ (Engleman et al., 1985). The $\mathrm{CO}_{2}$ released during this process was measured by titration in a coulometer cell. Samples with the highest concentration of $\mathrm{C}$ were analyzed by coulometry for inorganic $\mathrm{C}$. These analyses and loss-onignition analyses (Worona and Whitlock, 1995) indicated a negligible percentage of $\mathrm{CaCO}_{3}$, which sugests that most of the total $\mathrm{C}$ in Little Lake sediments is organic. Nitrogen concentrations were determined using a Carlo Erba NA 1500 analyzer. Samples were combusted in oxygen at $1000^{\circ} \mathrm{C}$, and the resulting $\mathrm{NO}$ was reduced to $\mathrm{N}_{2}$. $\mathrm{N}_{2}$ was separated by chromatography and measured with a thermal conductivity detector. Sediments were also analyzed for 21 major and trace elements by induction-coupled, argon plasma emission spectrometry (ICP; Litchie et al., 1987).

The reconstruction of vegetation and climate from pollen percentages and accumulation rates was based on recent compilations of modern pollen, vegetation, and climate data from the Pacific Northwest (Minckley and Whitlock, 2000; Pellat et al., 1997). A square-chord measurement of dissimilarity (Overpeck et al., 1985) was used to compare modern and fossil pollen spectra of the 12 most abundant tree types. Square-chord values of less than 0.15 , of $0.15-0.20$, and of $0.20-0.30$ were used to identify "good analogues," "probable analogues," and "possible or weak analogues," respectively (see method described by Anderson et al., 1989). Most analogues between 42,500 and 27,600 cal yr B.P., were good to probable, which allowed for the estimation of specific paleoclimate parameters (Table 1).

TABLE 1

Description, vegetation type, and inferred climate of pollen subzones within Zone LL-1

\begin{tabular}{|c|c|c|c|}
\hline $\begin{array}{l}\text { Pollen subzone } \\
\text { age (cal yr B.P.) } \\
\text { depth }(\mathrm{m})\end{array}$ & Pollen description & $\begin{array}{l}\text { Vegetation type } \\
\text { and square-chord } \\
\text { distances }\end{array}$ & $\begin{array}{l}\text { Inferred } \\
\text { climate }\end{array}$ \\
\hline $\begin{array}{l}\text { LL- } 1 \mathrm{~h} \\
\text { 26,490-27,810 cal } \\
\text { yr B.P. } 14.36-14.64 \mathrm{~m}\end{array}$ & $\begin{array}{l}\text { High percentages of Pinus (haploxylon- and diploxylon-types) } \\
\quad(20-60 \%) \text { and Abies }(15-20 \%) \text {; increases in percentages of } \\
\text { Picea }(5-20 \%), \text { T. mertensiana }(5-10 \%) \text {, and herbs }(10-25 \%) \text { at } \\
\text { end of subzone. Total accumulation of terrestrial pollen and } \\
\text { spores (PAR): } 1000-1900 \mathrm{~g} / \mathrm{cm}^{2} / \mathrm{yr} \text {. }\end{array}$ & $\begin{array}{l}\text { Montane to subalpine forest; } \\
\text { Sq. chord }=0.15-0.20 \\
\text { (probable analogue) }\end{array}$ & Cold, wet \\
\hline $\begin{array}{l}\text { LL-1g } \\
27,810-28,300 \mathrm{cal} \\
\text { yr B.P. } 14.64-14.74 \mathrm{~m}\end{array}$ & $\begin{array}{l}\text { High percentages of Tsuga heterophylla (40\%) and Abies } \\
\quad(15 \%) \text {; small increases in percentages of Cupressaceae }(8 \%) \\
\text { and Pseudotsuga-type (2-5\%). PAR: } 1700-2900 \mathrm{~g} / \mathrm{cm}^{2} / \mathrm{yr} \text {. }\end{array}$ & $\begin{array}{l}\text { Montane forest; Sq. chord }<0.15 \\
\quad \text { (good analogue) }\end{array}$ & Cool, wet \\
\hline $\begin{array}{l}\text { LL-1f } \\
\text { 28,300-32,450 cal } \\
\text { yr B.P. } 14.74-15.54 \mathrm{~m}\end{array}$ & $\begin{array}{l}\text { High percentages of Pinus (haploxylon-type) }(30-80 \%) \text { and } \\
\text { small increases in herbs }(5-15 \%) \text { and at the top of the subzone, } \\
\text { Picea }(2-5 \%) \text { and Tsuga mertensiana }(2-5 \%) \text { alternate with } \\
\text { peaks in Abies }(5-25 \%), \text { T. heterophylla }(5-15 \%), \text { Pseudotsuga- } \\
\text { type }(2 \%) \text { and Cupressaceae (2-5\%); moderate percentages of } \\
\text { Alnus sinuata-type }(5-15 \%) \text { and Alnus rubra-type (2-5\%) } \\
\text { PAR: } 1350-5400 \mathrm{~g} / \mathrm{cm}^{2} / \mathrm{yr} \text {. }\end{array}$ & $\begin{array}{l}\text { Alternating Pinus-dominated and } \\
\text { temperate forests; Sq. chord }= \\
0.15-0.20 \text { (probable analogue) }\end{array}$ & $\begin{array}{l}\text { Alternating cold, dry } \\
\text { and cool, wet }\end{array}$ \\
\hline $\begin{array}{l}\text { LL-1e } \\
\text { 32,450-33,330 cal } \\
\text { yr B.P. } 15.54-15.70 \mathrm{~m}\end{array}$ & $\begin{array}{l}\text { Significant increases in percentages of Abies }(15-25 \%), T \text {. } \\
\text { heterophylla (5-35\%), Pseudotsuga-type (5-7\%) Cupressaceae } \\
\text { (5-10\%) and Alnus rubra-type (5-10\%); decline in percentages } \\
\text { of Pinus (haploxylon-type) (20-35\%). PAR: } 2500-4600 \mathrm{~g} / \mathrm{cm}^{2} / \mathrm{yr} \text {. }\end{array}$ & $\begin{array}{l}\text { Temperate forest; Sq. chord }=0.15- \\
0.20 \text { (probable analogue) }\end{array}$ & Warm, wet \\
\hline $\begin{array}{l}\text { LL-1d } \\
\text { 33,330-35,870 cal } \\
\text { yr B.P. } 15.70-16.14 \mathrm{~m}\end{array}$ & $\begin{array}{l}\text { Generally high percentages of Pinus (haploxylon-type; } 25- \\
60 \%) \text {, herbs (10-20\%), and Abies (10-15\%); small increases in } \\
\text { percentages of T.mertensiana }(2-5 \%) \text {, Picea }(2-5 \%) \text { and } \\
\text { Alnus sinuata-type }(5-10 \%) \text {. PAR: } 1350-3250 \mathrm{~g} / \mathrm{cm}^{2} / \mathrm{yr} \text {. }\end{array}$ & $\begin{array}{l}\text { Pinus-dominated subalpine forest; } \\
\text { Sq. chord }<0.15 \text { (good analogue) }\end{array}$ & Cold, wet \\
\hline $\begin{array}{l}\text { LL-1c } \\
\text { 35,870-39,500 cal } \\
\text { yr B.P. } 16.14-16.74 \mathrm{~m}\end{array}$ & $\begin{array}{l}\text { Generally high percentages of Pinus (haploxylon-type; 15- } \\
\text { 65\%) alternate with peaks in T. heterophylla }(10-30 \%) \text { and } \\
\text { Abies (5-20\%); moderate percentages of herbs }(15-20 \%), \\
\text { Cupressaceae and Alnus sinuata-type (5-10\%); percentages of } \\
\text { Alnus rubra-type decline and T. mertensiana }(5 \%) \text { and Picea } \\
\text { (5-7\%) briefly increase toward the bottom of the subzone. } \\
\text { PAR: } 900-4100 \mathrm{~g} / \mathrm{cm}^{2} / \mathrm{yr} \text {. }\end{array}$ & $\begin{array}{l}\text { Alternating Pinus-dominated and } \\
\text { montane forests; Sq. chord }=0.15- \\
0.20 \text { (probable analogue) }\end{array}$ & $\begin{array}{l}\text { Alternating cool, wet } \\
\text { and cold, dry }\end{array}$ \\
\hline $\begin{array}{l}\text { LL- } 1 \mathrm{~b} \\
\text { 39,500-40,310 cal } \\
\text { yr B.P. } 16.74-16.86 \mathrm{~m}\end{array}$ & $\begin{array}{l}\text { High percentages of } T \text {. heterophylla }(35 \%) \text {, Pseudotsuga-type } \\
\text { (5-10\%), and Cupressaceae }(10-15 \%) \text {; decline in percentages } \\
\text { of Pinus (haploxylon-type; } 10-15 \%) \text { and Alnus sinuata-type } \\
\text { (<5\%). PAR: } 1500-2100 \mathrm{~g} / \mathrm{cm}^{2} / \mathrm{yr} \text {. }\end{array}$ & $\begin{array}{l}\text { Temperate forest; Sq. chord }= \\
0.15-0.20 \text { (probable analogue) }\end{array}$ & Warm, wet \\
\hline $\begin{array}{l}\text { LL-1a } \\
\text { 40,310-42,680 cal } \\
\text { yr B.P. } 16.86-17.22 \mathrm{~m}\end{array}$ & $\begin{array}{l}\text { High percentages of Pinus (haploxylon-type; } 25-60 \%) \\
\text { alternate with high percentages of T. heterophylla }(20-30 \%) \\
\text { and Abies (15-35\%); moderate percentages of Alnus sinuata- } \\
\text { type }(5-10 \%) \text {. PAR: } 1000-2600 \mathrm{~g} / \mathrm{cm}^{2} / \mathrm{yr} \text {. }\end{array}$ & $\begin{array}{l}\text { Pinus-dominated forest; Sq. chord } \\
\quad<0.15 \text { (good analogue) }\end{array}$ & Cool, wet \\
\hline
\end{tabular}

Note. PAR, pollen accumulation rate. 
TABLE 2

Description, Vegetation Type, and Inferred Climate of Pollen Subzones within Zone LL-2

Pollen subzone

age (cal yr B.P.) depth $(\mathrm{m})$

LL-2h

$14,140-15,730 \mathrm{cal}$ yr B.P. $10.56-11.30 \mathrm{~m}$

LL-2g

15,730-17,250 cal yr B.P. 11.30-11.88 m

\section{LL-2f \\ $17,250-20,220 \mathrm{cal}$ yr B.P. $11.88-12.82 \mathrm{~m}$}

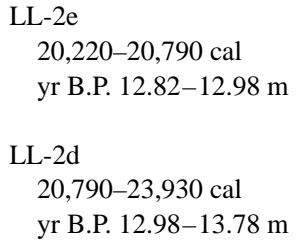

20,790-23,930 cal yr B.P. $12.98-13.78 \mathrm{~m}$

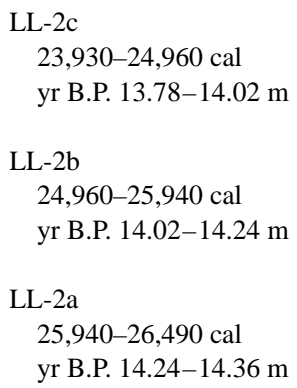

High percentages of Alnus sinuata-type (10-15\%) and herbaceous taxa (20\%); increasing percentages of Tsuga heterophylla (10\%) and Pteridophytes (10\%) toward top of subzone. Total accumulation of terrestrial pollen and spores. PAR: $2100-5300 \mathrm{~g} / \mathrm{cm}^{2} / \mathrm{yr}$.

Base of zone begins with high percentages of Picea (20$25 \%$ ) and is replaced by Tsuga mertensiana (20-25\%), Abies (15-35\%), and herbaceous taxa (25\%); percentages in the above taxa decline after $16,540 \mathrm{cal}$ yr B.P. when percentages of $T$. heterophylla $(10 \%)$, Alnus sinuata-type (5\%), and Pteridophytes (15-20\%) increase. PAR: 1200 $3100 \mathrm{~g} / \mathrm{cm}^{2} / \mathrm{yr}$.

Generally high percentages of herbs (15-40\%) dominate this zone; periodic increases in Pinus (diploxylon-type) (15-35\%), Picea (10-20\%), T. mertensiana (5-20\%), and Abies (10-20\%) also characterize this subzone. PAR: 740 $2300 \mathrm{~g} / \mathrm{cm}^{2} / \mathrm{yr}$.

High percentages of herbs (25\%), T. mertensiana (20\%), and Picea (20\%). PAR: $1200-2400 \mathrm{~g} / \mathrm{cm}^{2} / \mathrm{yr}$.

Generally high percentages of Pinus (diploxylon-type) (20-60\%) alternate with peaks in Picea (10-20\%), T. mertensiana (5-20\%), Abies (5-20\%), and small increases in T. heterophylla (5-10\%); high percentages of herbs (15$25 \%$ ) separate peaks in Pinus and associated taxa. PAR: $830-2670 \mathrm{~g} / \mathrm{cm}^{2} / \mathrm{yr}$.

High percentages of Pinus (haploxylon-type; 20-60\%) and herbs (5-20\%). PAR: $900-2000 \mathrm{~g} / \mathrm{cm}^{2} / \mathrm{yr}$.

High percentages of Pinus (diploxylon-type; 20-40\%) and Abies (10-20\%); moderate increase in percentages of $T$. heterophylla (5-15\%) at end of subzone. PAR: 500-2500 g/ $\mathrm{cm}^{2} / \mathrm{yr}$.

High percentages of Picea (20-30\%), T. mertensiana (30\%), and Abies (20-30\%). PAR: $1200-2100 \mathrm{~g} / \mathrm{cm}^{2} / \mathrm{yr}$.
Vegetation type and square-chord distances

Inferred climate
Developing montane forest; Sq. chord $<0.15$ (good analogue)

Wet, subalpine to montane forests; Sq. chord $=0.20-0.30$ (possible analogue)

Dry, subalpine forest and parkland; Sq. chord $=0.20-0.30$ (possible analogue)

Wet, subalpine forest; sq. chord $=$ 0.20-0.30 (possible analogue)

Alternating wet, subalpine and dry subalpine forests; Sq. chord = $0.20-0.30$ (possible analogue)

Dry subalpine forest/parkland; Sq. chord $=0.20-0.30$ (possible analogue)

Montane forest; Sq. chord $=0.20-0.30$ (possible analogue)

Wet, subalpine forest; Sq. chord = 0.15-0.20 (probable analogue)
Cool, wet

Cold, wet changing to cool, wet

Coldest and driest

Cold, wet

Alternating cold, wet and cold, dry

Cold, dry

Cool, wet

Cold, wet

Note. PAR, pollen accumulation rate.

Between 27,600 and 14,100 cal yr B.P., most analogues were possible or weak, which limited reconstructions to more qualitative estimates that were based on established relationships between present-day pollen percentages, vegetation abundance, and climate for specific taxa (Table 2; Minckley and Whitlock, 2000; Pellat et al., 1997; Thompson et al., 1999).

\section{CHRONOLOGY}

The chronology for the last glacial period at Little Lake is based on 11 accelerator mass spectrometry (AMS) radiocarbon dates of charcoal and plant macrofossils (Table 3). Radiocarbon ages $<20,300{ }^{14} \mathrm{C}$ yr B.P. were calibrated using the CALIB 4.0 program (Stuiver and Reimer, 1993). Radiocarbon ages from 20,300 to $28,000{ }^{14} \mathrm{C}$ yr B.P. were calibrated using a lake varve data set from Lake Suigetsu, Japan (Kitagawa and van der Plicht, 1998). Calibrated age-ranges were derived using Method B from CALIB 4.0, which constructs a probability distribution of calibrated ages for any given radiocarbon age (see Stuiver and Reimer, 1993). This method includes both the sample and calibration curve error in the calculation of calibrated age-ranges.

For radiocarbon ages $>28,000{ }^{14} \mathrm{C}$ yr B.P., a calibration curve was estimated using the Lake Suigetsu data set, a U/Th and ${ }^{14} \mathrm{C}$ dated coral sample from New Guinea, and paleomagnetic data that indicate atmospheric $\Delta^{14} \mathrm{C}$ changes close to zero at $50,000{ }^{14}$ C yr B.P. (Kitagawa and van der Plicht, 1988; Bard 
TABLE 3

Radiocarbon D ates and Calibrated Ages from the Last G lacial Period for Little Lake

\begin{tabular}{|c|c|c|c|c|}
\hline Depth (m) & Material dated & Lab No. & $\begin{array}{l}\text { Radiocarbon age } \\
\left({ }^{14} \mathrm{C} \text { yr B.P. }\right)\end{array}$ & $\begin{array}{l}{ }^{a} \text { Calibrated age (cal yr } \\
\text { B.P.) and } 2 \sigma \text { range }\end{array}$ \\
\hline $11.67-11.70$ & charcoal, wood & AA-27839 & $14,200 \pm 170$ & $17,030(16590-17540)$ \\
\hline $11.89-11.93$ & charcoal, wood & Beta-111337 & $13,140 \pm 160$ & $15,650(15,060-16,150)$ \\
\hline $11.89-11.93$ & lake sediment & Beta-111336 & $15,340 \pm 130$ & $18,260(17,950-18,560)$ \\
\hline $12.48-12.51$ & charcoal, wood & AA-27840 & $15,220 \pm 150$ & $18,140(17,790-18,480)$ \\
\hline $13.41-13.45$ & charcoal, wood & AA-27841 & $19,440 \pm 340$ & $23,100(22,480-23,890)$ \\
\hline $13.99-14.01$ & charcoal, wood & AA-27842 & $22,790 \pm 570$ & $26,320(25,130-27,730)$ \\
\hline $14.69-14.73$ & charcoal, wood & AA-27843 & $26,360 \pm 540$ & $29,741(28,230-31,570)$ \\
\hline $15.49-15.52$ & charcoal, wood & AA-27844 & $25,540 \pm 700$ & $28,960(27,370-30,830)$ \\
\hline $16.48-16.52$ & charcoal, wood & AA-31360 & $32,030 \pm 940$ & $36,260(35,160-37,500)$ \\
\hline 17.26 & wood & AA- 27846 & $42,700 \pm 1700$ & $44,720(43,800-45,780)$ \\
\hline
\end{tabular}

${ }^{a}$ Calibrated ages were used to derive the age model for Little Lake. See text for discussion of calibration.

et al., 1998; Mazuad et al., 1991). From 28,000 to $50,000{ }^{14} \mathrm{C}$ yr B.P., a discrepancy of $5000 \mathrm{yr}$ exists between the lake and coral data sets (Kitagawa and van der Plicht, 1998). To utilize all existing data sets, a curve was fit that approximated between the coral and lake varve data sets and assumed a $\Delta^{14} \mathrm{C}$ of zero at $50,000{ }^{14} \mathrm{C}$ yr B.P. Calibrated age-ranges were derived using a probability distribution, and a second-order polynomial was used to construct an age vs. depth model for the calibrated ages (Fig. 2).

\section{RESULTS}

\section{Lithology, Geochemical, and Magnetic Susceptibility Data}

The bedrock surrounding Little Lake consists of noncarbonate volcanic sedimentary rocks. The core contains mostly in-

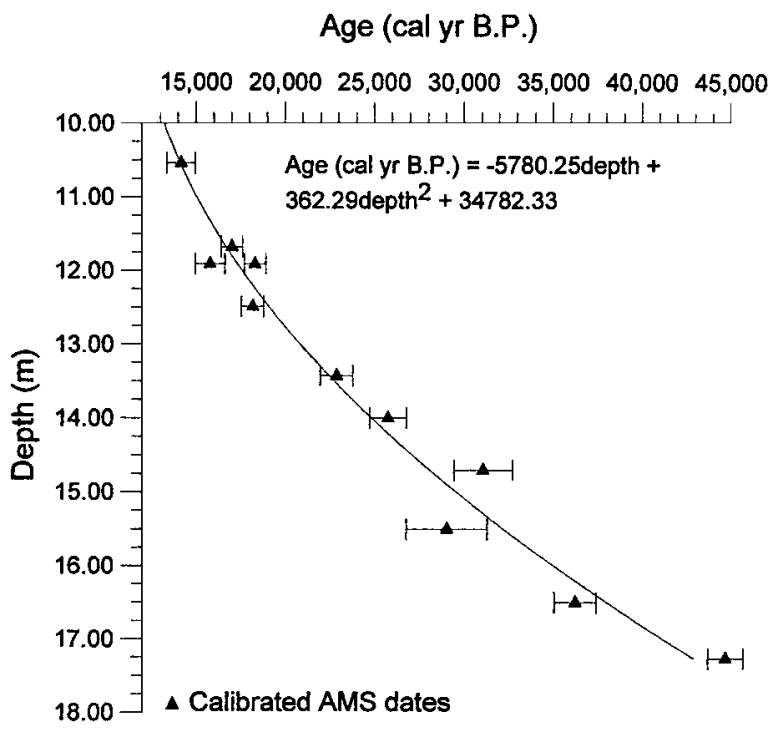

FIG. 2. Age-vs.-depth curve and regression equation for the last glacial period at Little Lake. Age model was developed using calibrated radiocarbon ages, which are shown with two sigma error bars. See text for discussion of calibration. organic clay, silt, and fine sand with discontinuous lenses of organic material (2\%-3\% organic carbon $(\mathrm{OC})$ ) from 10.56 to $14.62 \mathrm{~m}$ depth. The sediment from 14.62 to $16.42 \mathrm{~m}$ depth is similar but with more discontinuous lenses of organic material (2-4\% OC), and a section of gyttja (3-5\% OC) from 16.04 to $16.35 \mathrm{~m}$ depth. Results of ICP elemental analyses of common lithophile elements (e.g., Al, K, Mg, Ti, Li, Ni, V, and Z) did not reveal any significant patterns of variability, suggesting that the source of detrital clastic material into Little Lake remained constant.

The concentration of OC in sediments deposited during Zone LL-1 fluctuates between 1.75 and 5\% (Fig. 3). Peaks in total $\mathrm{N}$ generally correspond to peaks $(>3 \%)$ in $\mathrm{OC}$, with an overall correlation coefficient of 0.85 . Values of $\mathrm{C} / \mathrm{N}$ in sediments deposited during Zone LL-1 are mostly >10 (up to 16), suggesting that much of the organic matter was likely from terrestrial allochthonous sources (Meyers and Ishiwatari, 1993). Total S concentration averages $>0.2 \%$ in sediments deposited during Zone LL-1, with peaks of up to $0.5 \%$ corresponding with peaks in $\mathrm{C}$ concentration $(r=0.80, n=71)$. The concentration of $\mathrm{Fe}$ is low and invariant in sediments deposited during Zone LL-1, which indicates that the $S$ is likely from organic sources, rather than from Fe sulfide mineral. High concentrations of OC and $\mathrm{S}$ are concurrent with low values of magnetic susceptibility. These data suggest that the preservation of organic matter periodically increased as a result of increased anoxia in the bottom waters.

During Zone LL-2, OC and S concentrations are relatively constant with an average of ca. $2 \%$ and $0.1 \%$, respectively. Values of $\mathrm{N}$ average ca. 0.2 , and $\mathrm{C} / \mathrm{N}$ ratios average 9.5, suggesting that the organic matter is mostly autochthonous (Meyers and Ishiwatari, 1993). Generally high values of magnetic susceptibility in sediments deposited during Zone LL-2, together with low OC and S concentrations, indicate decreased preservation of organic matter and the occurrence of oxic conditions. These data are consistent with high and variable concentrations of $\mathrm{Fe}$ and Mn, which imply that the hypolimnion and sediment pore waters were well oxygenated, resulting in the preservation of oxidized $\mathrm{Fe}$ and $\mathrm{Mn}$ minerals. 


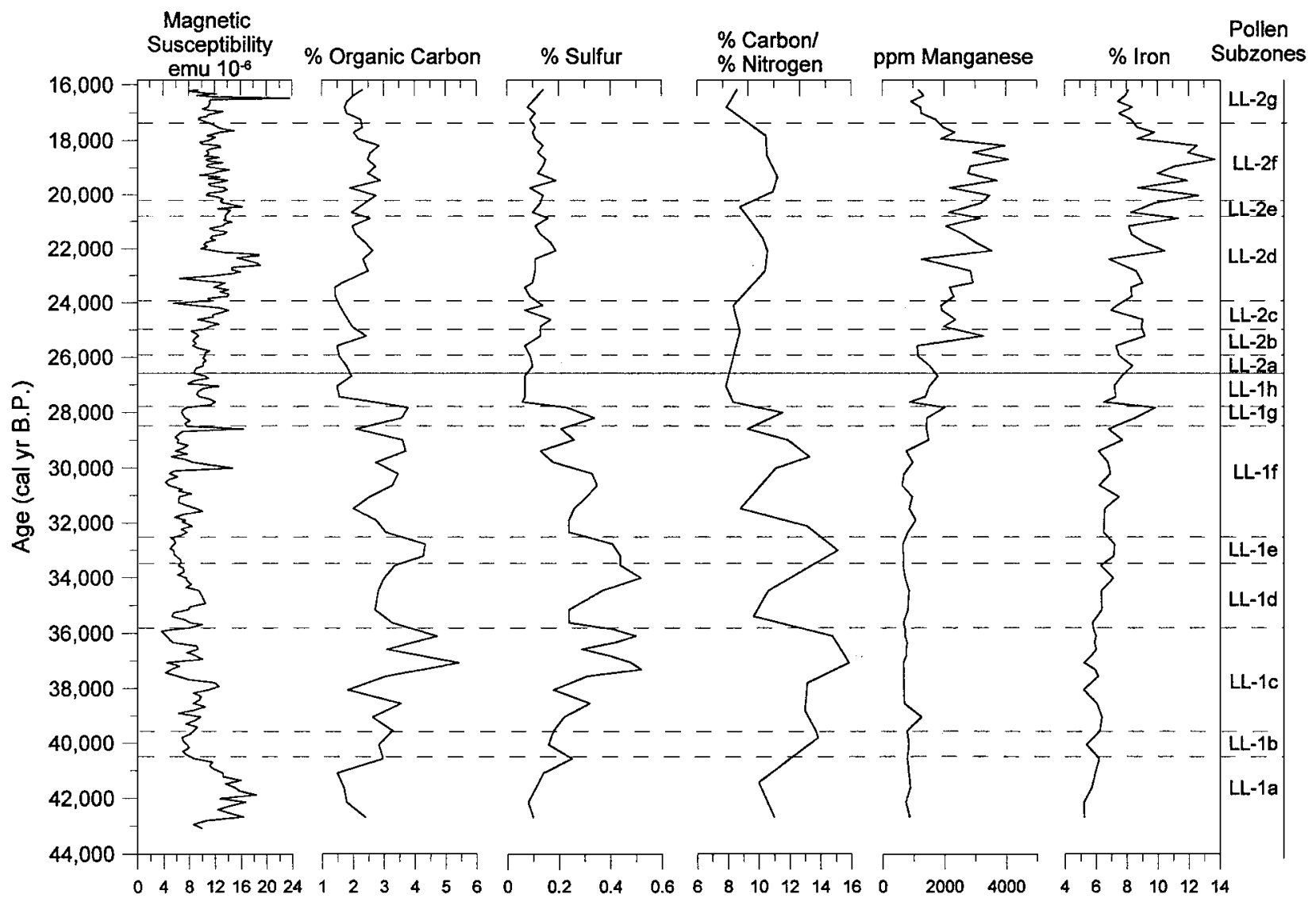

FIG. 3. Magnetic susceptibility and geochemical data from Little Lake.

\section{Vegetation and Climate Reconstructions}

The last glacial period at Little Lake is represented by pollen zones LL-1 (42,500-27,000 cal yr B.P.) and LL-2 (27,00015,000 cal yr B.P.; Worona and Whitlock, 1995), corresponding to the latter part of MIS 3 and to MIS 2, respectively. Zone LL-1 is generally characterized by high percentages and accumulation rates of Pinus (mostly haploxylon-type), Abies, and T. heterophylla pollen (Table 1; Figs. 4 and 5). Zone LL-2 is dominated by generally high pollen percentages and accumulation rates of Picea, T. mertensiana, Abies, Pinus (mostly diploxylontype), and herbaceous taxa (Table 2; Figs. 6 and 5).

Picea pollen in Zone LL-1 is most likely from Picea engelmannii (Engelmann spruce) based on its association with T. mertensiana and Abies in Oregon today. However, the presence of $P$. sitchensis (Sitka spruce) cannot be ruled out, because it currently grows with $T$. mertensiana in coastal British Columbia (Meidinger and Pojar, 1991). Haploxylon-type Pinus pollen is likely from $P$. monticola based on its occurrence with $T$. heterophylla and Abies. Pseudotsuga-type pollen is probably from Pseudotsuga menziesii rather than Larix (larch), which is rare west of the Cascade Range. The association of Cupressaceae with T. heterophylla and Pseudotsuga-type pollen suggests that it is probably from Thuja plicata or Libocedrus decurrens (in- cense cedar). Abies pollen is not consistently associated with any one taxa, which implies that it could be from a number of common species, including $A$. amabilis (Pacific silver fir), $A$. grandis, A. procera (noble fir), and A. lasiocarpa (subalpine fir). Most of the fossil pollen assemblages from Zone LL-1 are similar to modern pollen spectra from montane (ca. 900-1500 m elevation) and subalpine (ca. 1300-2000 m elevation) forests from the Cascade Range in Oregon and Washington (Franklin and Dyrness, 1988; Table 1; Figs. 4 and 6). The presence of such forests at Little Lake indicates conditions were ca. $4^{\circ}-8^{\circ} \mathrm{C}$ cooler than today and about as wet as present. Wet conditions are consistent with $\mathrm{C} / \mathrm{N}$ values, which suggest an allochthonous OC source and increased erosion. Generally high but variable values of OC and S and low magnetic susceptibility imply anoxic conditions that were probably related to relatively warm conditions and long periods of thermal stratification.

During Subzone LL-1a, high percentages of T. heterophylla and Cupressaceae pollen are replaced by those of Abies and Pinus (mostly haploxylon-type) pollen at ca. 42,250 cal yr B.P. This shift in dominance reflects a transition from montane to subalpine forest and from cool to cold conditions. High magnetic susceptibility and low percentages of OC suggest oxic conditions that were likely related to a relatively short period of thermal stratification (Fig. 3). The vegetation during Subzone 


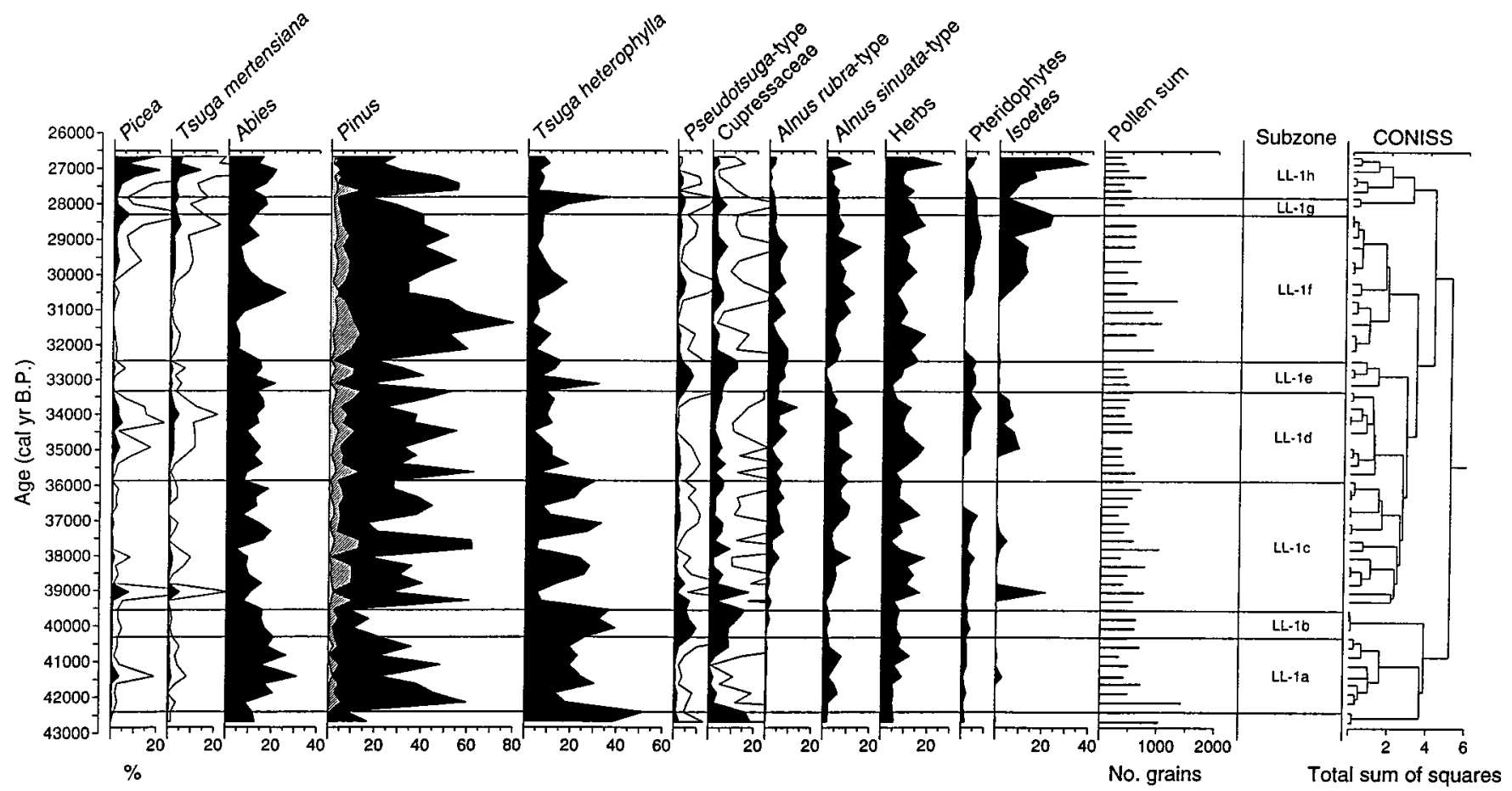

FIG . 4. Pollen percentage diagram for selected Little Lake taxa during the latter part of marine isotope stage 3. Open curves represent fivefold exaggeration of black curves. Pinus includes haploxylon-type (P. monticola) and is shown with a stripped curve, diploxylon-type ( $P$. contorta or $P$. ponderosa) is represented by an open curve, and total Pinus is shown with a black curve. The results of a constrained cluster analysis are illustrated.

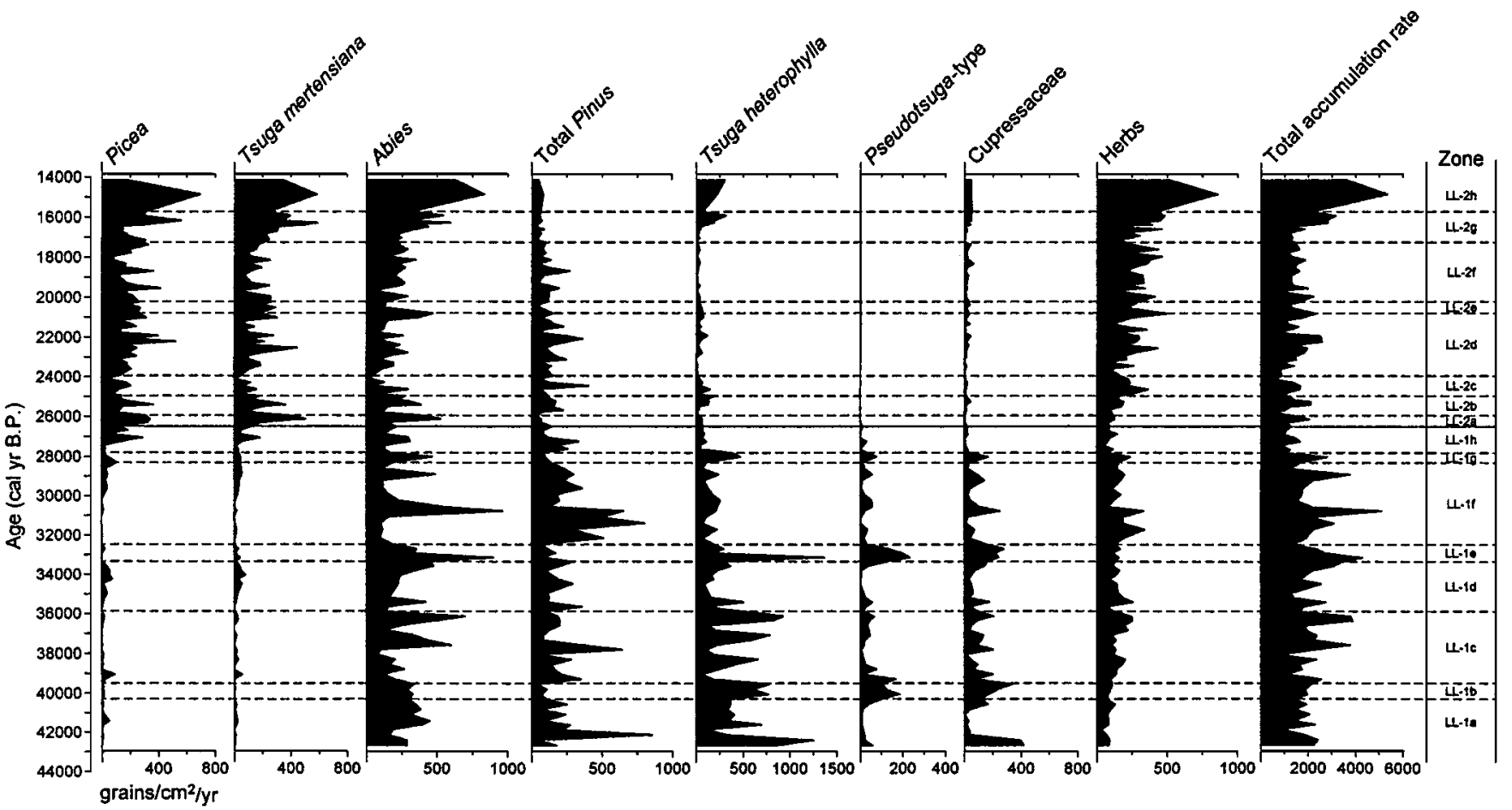

FIG . 5. Pollen accumulation rates for selected Little Lake taxa during zones LL-1 and LL-2. 


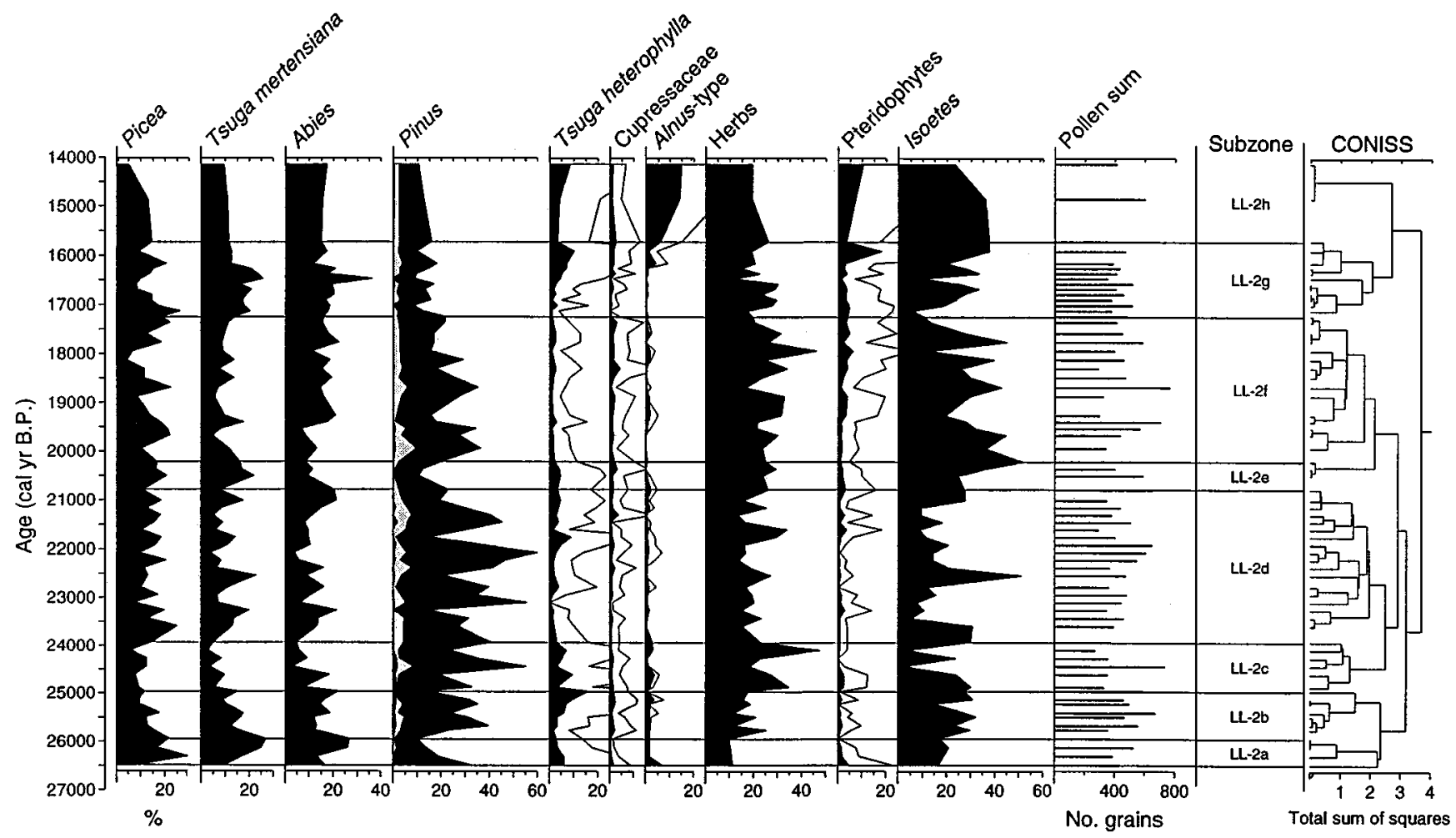

FIG. 6. Pollen percentage diagram for selected Little Lake taxa during marine isotope stage 2. Open curves represent fivefold exaggeration of black curves. Pinus includes haploxylon-type ( $P$. monticola or $P$. albicaulis) and is shown with a stripped curve, diploxylon-type $(P$. contorta or $P$. ponderosa) is represented by an open curve, and total Pinus is shown with a black curve. The results of a constrained cluster analysis are illustrated.

LL-1b was probably similar to modern montane or low-elevation temperate forests based on high pollen percentages of $T$. heterophylla, Pseudotsuga-type, and Cupressaceae. These taxa imply some of the warmest conditions of Zone LL-1 (mean annual temperature estimated at $5^{\circ}-6^{\circ} \mathrm{C}$ ). Low magnetic susceptibility and high percentages of $\mathrm{OC}$ indicate a period of increased anoxia.

Subzone LL-1c is characterized by a series of fluctuations between Pinus (haploxylon-type) and T. heterophylla pollen that probably represent shifts between montane forests of $T$. heterophylla and those of Pinus (P. monticola). Although $T$. heterophylla and $P$. monticola have overlapping climate ranges, $P$. monticola tends to grow in areas with colder winter temperatures and less summer precipitation than T. heterophylla (Thompson et al., 1999). The high frequency fluctuations between $T$. heterophylla and $P$. monticola therefore imply that the climate oscillated three times from cool, wet conditions (mean annual temperatures estimated at $4^{\circ}-5^{\circ} \mathrm{C}$ ), to colder and possibly drier conditions (mean annual temperatures estimated at $3^{\circ}-4^{\circ} \mathrm{C}$ ). Peaks in OC and $\mathrm{S}$ and low magnetic susceptibility suggest increased anoxia during the $T$. heterophylla-dominated intervals.

Subzone LL-1d contains high percentages of Pinus (haploxylon-type) and Abies pollen, and minor amounts of Picea and T. mertensiana pollen, which indicate the establishment of a subalpine forest and one of the coldest periods of Zone LL-
1 (annual temperatures estimated at $2^{\circ}-4^{\circ} \mathrm{C}$ ). Precipitation was probably equivalent to that of the present day, although more of it would have been in the form of snow. Subzone LL-1d is also characterized by low values of OC and S, which suggest relatively oxic conditions.

During Subzone LL-1e, Pseudotsuga-type, Cupressaceae, and T. heterophylla pollen increase significantly. This shift suggests a transition to a montane or low-elevation temperate forest and to warmer conditions than the previous subzone (mean annual temperatures estimated at $5^{\circ}-6^{\circ} \mathrm{C}$ ). At the base of this subzone, $\mathrm{OC}$ and $\mathrm{S}$ percentages increase and magnetic susceptibility values decrease, indicating a period of increased anoxia.

Pinus percentages reach their peak during Subzone LL-1f and imply a montane forest probably dominated by P. monticola and colder conditions than the previous subzone (mean annual temperatures estimated at $3^{\circ}-4^{\circ} \mathrm{C}$ ). Increased pollen percentages of Abies and T. heterophylla and minor amounts of Pseudotsugatype and Cupressaceae at 30,500 cal yr B.P. indicate the establishment of a mixed montane and temperate forest and slightly warmer conditions. A peak in OC and S at 30,500 cal yr B.P. suggests anoxic conditions and a brief warming. PAR show an increase in T. heterophylla, Pseudotsuga-type, and Cupressaceae at 29,000 cal yr B.P. that coincides with a second peak in OC and S (Fig. 5). Thus, PAR and geochemical data imply another brief warm interval at 29,000 cal yr B.P. The return of Pinus pollen in the top of this subzone reflects the reestablishment 
of P. monticola and colder conditions. The latter part of Subzone LL-1f and Subzone LL-1g are characterized by an overall decrease in temperate and montane species (T. heterophylla, Pseudotsuga-type, Cupressaceae, and Alnus-types) and an increase in subalpine types (Picea, T. mertensiana, and Abies). This shift marks the transition from zones LL-1 to LL-2 and an estimated $2^{\circ}-4^{\circ} \mathrm{C}$ decrease in temperatures. Superimposed on this larger-scale trend is an increase in pollen percentages of T. heterophylla during Subzone LL1-g, which indicate a change to montane forest and warmer conditions than before. By the end of Subzone LL-1h, temperate and montane taxa are replaced by subalpine taxa.

Abies pollen in Zone LL-2 could be from several species common to montane and subalpine forests in the Pacific Northwest (A. amabilis, A. lasiocarpa, or A. procera). Picea pollen is probably from $P$. engelmannii based on the identification of a macrofossil needle at $11.70 \mathrm{~m}$ (ca. 16,700 cal yr B.P.). Diploxylontype Pinus pollen could either be from $P$. contorta (lodgepole pine) or $P$. ponderosa (ponderosa pine). However $P$. contorta is more commonly associated with subalpine species, such as T. mertensiana. The fossil pollen spectra from Zone LL-2 are similar to modern pollen assemblages from subalpine forests (ca. 1300-2000 m elevation) and upper treeline (ca. 1400-2200 m elevation) in the Pacific Northwest (Franklin and Dyrness, 1988; Pellat et al., 1997; Table 2; Figs. 5 and 6). Climate estimates based on these modern analogues suggest that temperatures were $7^{\circ}-11^{\circ} \mathrm{C}$ colder and precipitation was $250-500 \mathrm{~mm}$ less than present, values consistent with previous estimates (Worona and Whitlock, 1995). Dry conditions are also reflected in $\mathrm{C} / \mathrm{N}$ values that indicate an autochthonous source for the OC and that imply less erosion. OC and $\mathrm{S}$ percentages are considerably lower than in Zone LL-1, whereas magnetic susceptibility is higher, reflecting more oxic conditions (Fig. 3).

Subzones LL-2a through LL-2e are characterized by repeated fluctuations between high pollen percentages of Picea, Abies, and T. mertensiana and those of Pinus (mostly diploxylon-type). The spectra dominated by Picea, Abies, and T. mertensiana pollen are similar to those from modern mesic subalpine forests in coastal British Columbia (Pellat et al., 1997). The climate of this area is characterized by abundant year-round precipitation and cold temperatures. Intervals with abundant Pinus pollen are similar to $P$. contorta-dominated subalpine forests in Oregon and Washington and suggest a more xeric or seasonably wet subalpine forest. These fluctuations reflect a series of oscillations between cold-wet and cold-dry conditions. T. heterophylla pollen increases during subzones LL-2b and LL-2d (ca. 25,000 and 22,000 cal yr B.P.), suggesting more montane forests and slightly warmer and wetter conditions than before. Minor peaks in the percentages of OC and S overlap with these peaks in $T$. heterophylla and suggest relatively anoxic conditions. Increased herbaceous taxa at ca. 25,000 cal yr B.P. indicate the establishment of a more open forest and the onset of cold-dry conditions. This increase occurs at about the same time as levels of Fe, Mn, and magnetic susceptibility increase, implying that the lake was better mixed and more oxygenated, probably as a result of the more open forest and increased wind.

Few modern pollen assemblages are similar to Subzone LL2f. However, based on the composition of modern alpine communities, this assemblage implies a subalpine parkland dominated by A. lasiocarpa and Poaceae (grass family), similar to those growing at present on the eastern slopes of the Washington Cascades and Olympic Mountains (Franklin and Dyrness, 1988). These environments suggest the coldest and driest conditions of this zone. Subzone LL-2g marks the return of high pollen percentages of Picea, T. mertensiana, and Abies and a decline in herbaceous taxa, which indicate the development of a closed and mesic subalpine forest. A sharp decline in Fe and $\mathrm{Mn}$ implies increased lake stratification and anoxia that probably resulted from a more protective forest cover around the lake and from warmer conditions. Subzone LL-2h shows the first major increase in warm-adapted taxa (T. heterophylla and Alnus-type) and a decrease in subalpine taxa. These changes suggest a shift to montane forest and the onset of the warm-wet conditions that mark the end of the last glacial period.

\section{DISCUSSION}

\section{Summary of Changes at Little Lake and Comparison with Other Pacific Northwest Records}

The sum of nonarboreal pollen percentages is used as a measure of changes in vegetation cover near Little Lake (Fig. 7). The establishment of a relatively open forest between 25,000 and 17,000 cal yr B.P. is concurrent with an increase in oxidizing conditions in the hypolimnion, perhaps as a result of less protective forest cover around the margins of the lake. Effective precipitation is represented by the sum of the wet-adapted taxa, Abies and T. mertensiana, which are both currently associated with high annual precipitation and actual/potential evaporation (Minckley and Whitlock, 2000). After the establishment of a more open forest, intervals of high effective precipitation are associated with peaks in magnetic susceptibility, perhaps indicating increased erosion within the watershed. Millennial-scale changes in temperature are reflected by the sum of warm-adapted taxa (Pseudotsuga-type, Cupressaceae, and T. heterophylla) over the sum of cold-adapted taxa (Picea, T. mertensiana, and Poaceae). In Zone LL-1, fluctuations in Pinus (probably P. monticola) parellel the cold-adapted taxa. However, Pinus pollen was not included in the cold sum because the taxon reflects dry conditions during Zone LL-2. The warm intervals shown by this ratio are usually supported by corresponding periods of increased anoxia.

Many of the millennial-scale climate changes identified at Little Lake are evident in other records from the Pacific Northwest (Fig. 1). A series of peaks in arboreal pollen at Carp Lake suggests four warm and/or wet periods $(39,500,36,000,32,500$, and 29,000 cal yr B.P.), which correlate with warm intervals during Zone LL-1 (Whitlock and Bartlein, 1997). A record from the Kalaloch sea cliffs on the Olympic Peninsula, Washington, 

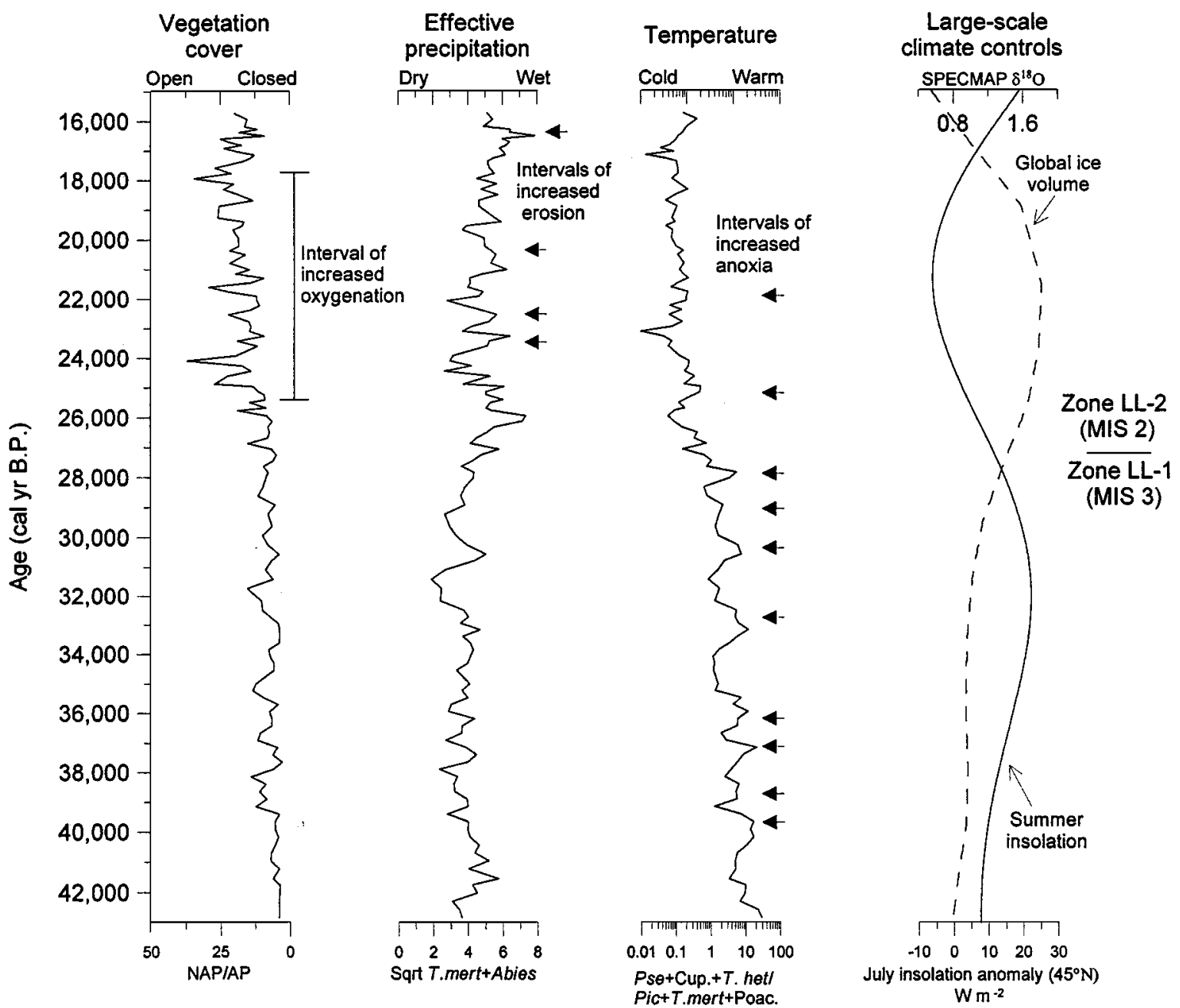

FIG. 7. Summary of changes in vegetation and climate at Little Lake during marine isotope stages 2 and 3 based on vegetation and climate indexes developed from the pollen data. Significant environmental changes inferred from the geochemical and magnetic susceptibility data are also shown. In the far right graph, variations in northern hemisphere summer insolation (Berger, 1978) are represented by a solid line. Global ice-volume, as inferred from the SPECMAP stacked and smoothed oxygen isotope data, is shown by the dashed line (Imbrie et al., 1984).

shows five fluctuations between arboreal and nonarboreal pollen taxa between ca. 40,000 and 27,000 cal yr B.P. (Heusser, 1972). Increased percentages of Picea pollen at Carp Lake suggest cold, wet periods at ca. 26,000, 23,000, and 17,500 cal yr B.P., which are concurrent with the wet periods at Little Lake during Zone LL-2. Advances of the Cordilleran ice sheet in southwestern British Columbia also indicate cold, wet conditions between ca. 18,000 and 16,000 cal yr B.P. (Vashon Stade) and between ca. 24,500 and 22,000 cal yr B.P. (Coquitlam Stade; Hicock et al., 1999). The ca. 22,000 cal yr B.P. warm period at Little Lake is registered at other sites in the Pacific Northwest between 23,000 and 22,000 cal yr B.P. (Hicock et al., 1999; Mathewes, 1991; Whitlock and Grigg, 1999). These similarities in the direction and timing of vegetation changes throughout the Pacific Northwest imply that they represent a response to regional variations in climate.

\section{Influence of Orbital-Scale Climate Controls}

The generally moderate climate of the Pacific Northwest during MIS 3 (Alley, 1979; Barnosky, 1981, 1985; Heusser et al., 1999; Warner et al., 1984; Whitlock and Bartlein, 1997) corresponds with intermediate levels of summer insolation and global ice-volume. These orbital-scale controls fluctuated during MIS 3, but the highs and lows were not as dramatic as those of MIS 2 or the Holocene (Fig. 7). A comparison of MIS 3 climate changes at Little Lake with summer insolation and ice-volume suggests that variability in the magnitude of climate change partially reflects orbital-scale variations (Fig. 7). Two of the warmest periods of Zone LL-1 (at 33,000 and 30,500 cal yr B.P.) occurred during a period (33,000 to 30,500 cal yr B.P.), of high summer insolation and moderate ice volumes whereas the coldest intervals occurred before and after this time. Between 38,000 and 35,000 cal yr B.P. 
a series of moderate shifts in climate imply a generally cool and seasonably equable climate, which coincides with relatively low summer and moderate winter insolation. However, some of the warmest conditions occurred (40,000 cal yr B.P.) when summer insolation was low and ice-volumes were moderate, suggesting that variations in millennial-scale climate controls, independent of orbital-scale forcings, also influenced the degree of climate change at Little Lake during MIS 3.

During MIS 2 (27,600-14,100 cal yr B.P.), the presence of subalpine forest and parkland in many low-elevation areas of the Pacific Northwest indicates colder, drier conditions than at present (Alley, 1979; Barnosky, 1981, 1985; Heusser et al., 1999; Worona and Whitlock, 1995). Paleoclimate model simulations show that such conditions were related to the size of the Laurentide ice-sheet (Bartlein et al., 1998; Thompson et al., 1993) with the climate of the Pacific Northwest being affected by (1) the large extent of the ice-sheet causing a decrease in northern hemisphere temperatures; (2) the height of the ice-sheet displacing the jet stream to the south of its present position and; (3) the presence of a large ice-sheet resulting in a midcontinental, glacial anticyclone that increased easterly flow across western North America. The coldest and driest conditions occurred at Little Lake between ca. 21,000 and 17,000 cal yr B.P., which corresponds to a low in summer insolation and a maximum in global ice-volume.

\section{Causes of Millennial-Scale Climate Change at Little Lake}

A comparison of the Little Lake data with a record of seasurface temperatures and sediment bioturbation from the Santa Barbara Basin (Behl and Kennett, 1996; Hendy and Kennett, 1999) provides an opportunity to evaluate current explanations of millennial-scale climate change in western North America and the Northeast Pacific. The pollen-based temperature proxy from Little Lake, when compared with the bioturbation index from the Santa Barbara Basin, shows that low values coincide with warmer sea-surface temperatures (Fig. 8). The Santa Barbara record, like that from Little Lake, has the greatest frequency and magnitude of millennial-scale climate change during the latter part of MIS 3. Warm intervals are concurrent at both sites with the exception of the 38,500 cal yr B.P. warm period at Little Lake. This event is registered by an increase in T. heterophylla pollen and not by the warmestadapted taxa (Pseudotsuga-type or Cupressaceae). Consequently, it may reflect a modest climate warming or one of local extent.

Warmer sea-surface temperatures in the Santa Barbara Basin during MIS 3 have been attributed to northward shifts in the position of the subtropical high, the Aleutian low, and the jet stream (Hendy and Kennett, 1999). A significant northward shift of North Pacific atmospheric circulation patterns would have led to warmer year-round conditions in the Pacific Northwest and to a change from relatively dry to wet winters. Although this explanation is consistent with evidence for warming at Little Lake during the latter part of MIS 3, the lack of a strong precipitation

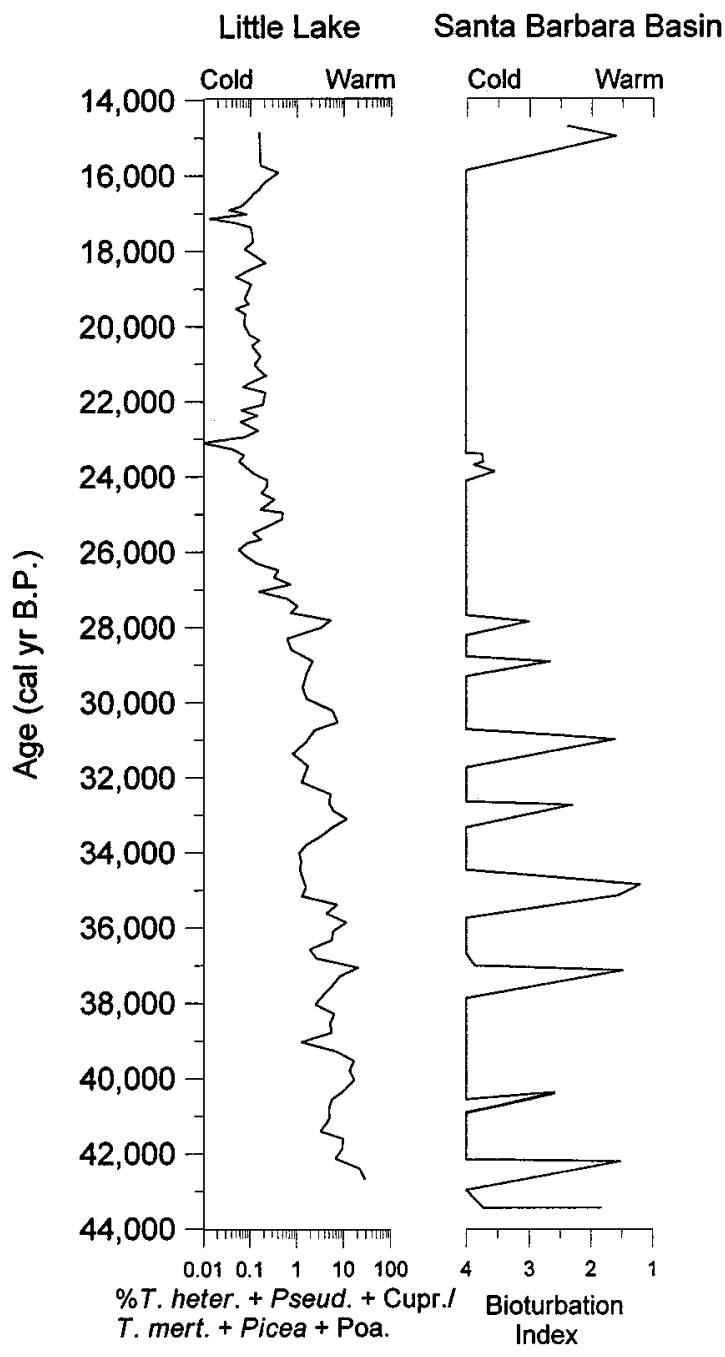

FIG. 8. A comparison of the pollen-based temperature ratio from Little Lake with the bioturbation index from Santa Barbara Basin (Behl and Kennett, 1996). A bioturbation index of four indicates periods of laminated sediments. Low values of the bioturbation index reflect intervals that correlate with warmer sea-surface temperatures (Hendy and Kennett, 1999).

signal implies little change in the position of the jet stream. In addition, strong upwelling along the central California margin suggests that the jet stream and subtropical high were close to their present positions (Gardner et al., 1997). An alternative explanation invokes variations in the strength of the subtropical high and the jet stream, without significant shifts in their position. A stronger subtropical high would explain warmer conditions in both the Santa Barbara Basin and the Pacific Northwest, while an increase in the strength of the jet stream would have caused a shift in the Pacific Northwest from wet to wetter winter conditions. This more subtle change may explain the evidence of only small increases in precipitation during warm intervals at Little Lake.

The correlation of MIS 3 sea-surface temperatures in the Santa Barbara Basin with changes in temperatures and surges in the Laurentide ice-sheet implies that variations in the strength 
of the subtropical high and jet stream may have been related to fluctuations in North Atlantic atmospheric and oceanic circulation and ice-sheet size. Other correlations do exist between western North America, Northeast Pacific and North Atlantic paleorecords (Benson, 1999; Hicock et al., 1999; Lin et al., 1998; Lund and Mix, 1998; Whitlock and Grigg, 1999). However, model simulations for western North America and the Northeast Pacific during MIS 2 and the late-glacial period show only small variations in temperature in response to changes in the height of the ice sheet and/or temperatures over the North Atlantic (Hostetler and Bartlein, 1999; Mikolajewicz et al., 1997). Shifts in Pacific sea-surface temperatures that were concurrent with North Atlantic changes may explain the degree of warming evident in the geologic record (Hostetler and Bartlein, 1999; Peteet et al., 1997).

Fluctuations between cold-wet and cold-dry conditions at Little Lake are not apparent in the Santa Barbara Basin during MIS 2 (Fig. 8). Changes in precipitation in the Pacific Northwest may be explained by variations in the strength of the glacial anticyclone and the latitude of the jet stream. A recent model simulation, which describes the potential responses of western North America to large surges in the Laurentide ice-sheet during Heinrich events, shows that a reduction in the height of the ice sheet results in a weakened glacial anticyclone and a less prominent split in the jet stream (Hostetler and Bartlein, 1999). As a result, westerly flow and precipitation increases in the Pacific Northwest, while southern California shows little change in climate. These results are supported by the correlation of cold, wet intervals in the Pacific Northwest at 23,500 and 17,000 cal yr B.P. with Heinrich events 1 and 2 (Bond and Lotti, 1995; Hicock et al., 1999; Whitlock and Grigg, 1999). In addition, cold wet intervals at 26,000 and 21,000 cal yr B.P. at Little Lake correspond to smaller and less established peaks in ice-rafted debris from the North Atlantic.

The warming at Little Lake at 22,500 cal yr B.P. is associated with widespread evidence in the Pacific Northwest for moderate warming between 23,000 and 22,000 cal yr B.P. (Mathewes, 1991; Whitlock and Grigg, 1999) and may correspond with a small increase in sea-surface temperatures in the Santa Barbara record at 23,500 cal yr B.P. However, an additional warm period at Little Lake at 25,000 cal yr B.P. is not matched in the Santa Barbara Basin record. Warming along the west coast of North America during MIS 2 may have resulted from a brief expansion of the subtropical high. Small changes in the subtropical high have been attributed to variations in Laurentide ice-sheet size and in North Atlantic atmospheric and oceanic circulation (Clark and Bartlein, 1995; Hendy and Kennett, 1999). However, model simulations of the last glacial maximum do not show warmer conditions along the coast in response to a reduction in ice-sheet height or an increase in sea-surface temperatures in the North Atlantic (Hostetler and Bartlein, 1999). Additional factors, such as an increase in sea-surface temperatures in the North Pacific, may have contributed to warming in western North America and the Northeast Pacific during this time (Hostetler and Bartlein, 1999; Peteet et al., 1997).

\section{ACKNOWLEDGMENTS}

We thank P. J. Bartlein for discussion and comments on the manuscript. C. J. Long and T. A. Minckley assisted in coring, and M. Glade provided help in the laboratory. Research was supported by National Science Foundation Grant ATM 9615822 to C. Whitlock.

\section{REFERENCES}

Alley, N. F. (1979). Middle Wisconsin stratigraphy and climatic reconstruction, southern Vancouver Island, British Columbia. Quaternary Research 11, 213-237.

Alley, R. B. (1998). Icing the North Atlantic. Nature 392, 335-337.

Anderson, P. M., Bartlein, P. J., Brubaker, L. B., Gajewski, K., and Ritchie, J. C. (1989). Modern analogues of late-Quaternary pollen spectra from the Western Interior of North America. Journal of Biogeography 161, 573-596.

Bard, E., Arnold, M., Hamelin, B., Tisnerat-Laborde, N., and Cabioch, G. (1998). Radiocarbon calibration by means of mass spectrometric ${ }^{230} \mathrm{Th} /{ }^{234} \mathrm{U}$ and ${ }^{14} \mathrm{C}$ ages of corals: An updated database including samples from Barbados, Mururoa and Tahiti. Radiocarbon 40, 1085-1092.

Barnosky, C. W. (1981). A record of late Quaternary vegetation from Davis Lake, southern Puget Lowland Washington. Quaternary Research 16, 221-239.

Barnosky, C. W. (1985). Late Quaternary vegetation near Battle Ground Lake, southern Puget Trough, Washington. Geological Society of America Bulletin 96, 263-271.

Bartlein, P. J., Anderson, K. H., Anderson, P. M., Edwards, M. E., Mock, C. J., Thompson, R. S., Webb, R. S., Webb, T., III, and Whitlock, C. (1998). Paleoclimate simulations for North America over the past 21,000 years: Features of the simulated climate and comparisons with paleoenviornmental data. Quaternary Science Reviews 17, 549-585.

Behl, R. J., and Kennett, J. P. (1996). Brief interstadial events in the Santa Barbara Basin, NE Pacific, during the past 60 kyr. Nature 379, 243-246.

Benson, L. (1999). Records of millennial-scale climate change from the Great Basin of the western United States. In "Mechansims of Global Climate Change at Millennial Time Scales” (P. U. Clark, R. S. Webb, and L. D. Keigwin, Eds.), pp. 203-225. American Geophys. Union, Washington DC.

Berger, A. (1978). Long-term variations of caloric insolation resulting from Earth's orbital elements. Quaternary Research 9, 139-167.

Bond, G. C., and Lotti, R. (1995). Iceberg discharges into the North Atlantic on millennial time scales during the last glaciation. Science 267, 10051009.

Bond, G. C., Showers, W., Cheseby, M., Lotti, R., Almasi, P., deMenocal, P., Priore, P., Cullen, H., Hajdas, I., and Bonani, G. (1997). A pervasive millennial-scale cycle in the North Atlantic Holocene and glacial climates. Science 278, 1257-1266.

Clark, P. U., and Bartlein, P. J. (1995). Correlation of late Pleistocene glaciation in the Western United States with North Atlantic Heinrich events. Geology 23, 483-486.

Cwynar, L. C., Burden, E. B., and McAndrews, J. H. (1979). An inexpensive method for concentrating pollen and spores from fine grained sediments. Canadian Journal of Earth Sciences 16, 1115-1120.

Engleman, E. E., Jackson, L. L., Norton, D. R., and Fischer, A. G. (1985). Determination of carbonate carbon in geologic materials by coulometric titration. Chemical Geology 35, 125-128.

Faegri, K., Kaland, P. E., and Krzywinski, K. (1989). "Textbook of Pollen Analysis." Wiley, London.

Franklin, J. F., and Dyrness, C. T. (1988). "Natural Vegetation of Oregon and Washington.” Oregon State Univ. Press, Corvallis, OR.

Gardner, J. V., Dean, W. E., and Dartnell, P. (1997). Biogenic sedimentation beneath the California current system for the past $30 \mathrm{kyr}$ and its paleoceanographic significance. Paleoceanography 12, 207-225. 
Grigg, L. D., and Whitlock, C. (1998). Late-glacial vegetation and climate changes in western Oregon. Quaternary Research 49, 287-298.

Grimm, E. C. (1988). Data analysis and display. In "Vegetation History" (B. Huntley and T. W. III, Eds.), pp. 43-76. Kluwer Academic, Dordrecht.

Hendy, I. L., and Kennett, J. P. (1999). Latest Quaternary North Pacific surfacewater responses imply atmosphere-driven climate instability. Geology 27, 291-294.

Heusser, C. J., Heusser, L. E., and Peteet, D. M. (1999). Humptulips revisted: A revised interpretation of Quaternary vegetation and climate of western Washington, USA. Palaeogeography, Palaeoclimatology, Palaeoecology 150, 191-221.

Hicock, S. R., Lian, O. B., and Mathewes, R. W. (1999). 'Bond cycles' recorded in terrestrial Pleistocene sediments of southwestern British Columbia, Canada. Journal of Quaternary Science 14, 443-449.

Hostetler, S. W., and Bartlein, P. J. (1999). Simulation of the potential responses of regional climate and surface processes in western North America to a canonical Heinrich event. In "Mechanisms of Global Climate Change at Millennial Timescales." (P. U. Clark, R. S. Webb, and L. D. Keigwin, Eds.), pp. 313-327. American Geophys. Union, Washington DC.

Heusser, C. J. (1972). Palynology and phytogeographical significance of a latepleistocene refugium near Kalaloch, Washington. Quaternary Research 2, 189-201.

Imbrie, J., Hays, J. D., Martinson, D. G., McIntyre, A., Mix, A. C., Morley, J. J., Pisias, N. G., Prell, W. L., and Shackleton, N. J. (1984). The orbital theory of Pleistocene climate: Support from a revised chronology of the marine $\delta^{18} \mathrm{O}$ record. In "Milankovitch and Climate" (A. Berger, J. Imbrie, J. Hays, G. Kukla, and B. Saltzman, Eds.), pp. 269-305. Reidel, Dordrecht.

Kitagawa, H., and van der Plicht, J. (1998). Atmospheric radiocarbon calibration to 45,000 yr B.P.: Late Glacial fluctuations and cosmogenic istope production. Science 279, 1187-1190.

Lin, J. O., Broecker, W. S., Hemming, S. R., Hajdas, I., Anderson, R. F., Smith, G. I., Kelley, M., and Bonani, G. (1998). A reassessment of U-Th and ${ }^{14} \mathrm{C}$ ages for late-glacial high-frequency hydrological events at Searles Lake, California. Quaternary Research 49, 11-23.

Litchie, F. E., Golightly, D. W., and Lamothe, P. J. (1987). Inductively coupled plasma-atomic emission spectrometry. In "Methods for Geochemical Analysis." (P. A. Baedecker, Ed.), USGS Bulletin 1770, B1-B10.

Long, C. J., Whitlock, C., Bartlein, P. J., and Millspaugh, S. H. (1998). A $9000-$ year fire history from the Oregon Coast Range, based on a high-resolution charcoal study. Canadian Journal of Forest Research 28, 774-787.

Lund, D. C., and Mix, A. C. (1998). Millennial-scale deep water oscillations: Reflections of the North Atlantic in the deep Pacific from 10 to 60 ka. Paleoceanography, 13, 10-19.

Mathewes, R. W. (1991). Climatic conditions in the western and northern Cordillera during the last glaciation: Paleoecologcial evidence. Géographie Physique et Quaternaire 45, 333-339.

Mazaud, A., Laj, C., Bard, E., Arnold, M., and Tric, E. (1991). Geomagnetic field control of ${ }^{14} \mathrm{C}$ production over the last $80 \mathrm{ky}$ : Implications for the radiocarbon time-scale. Geophysical Research Letters 18, 1885-1888.

McAndrews, J. H., Berti, A. A., and Norris, G. (1973). "Key to the Quaternary Pollen and Spores of the Great Lakes Region." Royal Ontario Museum, Toronto.

Meidinger, D., and Pojar, J. (1991). "Ecosystems of British Columbia.” British Columbia Ministry of Forests, Victoria.
Meyers, P. A., and Ishiwatari, R. (1993). Lacustrine organic geochemistryAn overview of indicators of organic matter sources and diagenesis in lake sediments. Organic Geochemistry 20, 867-900.

Mikolajewicz, U., Crowley, T. J., Schiller, A., and Voss, R. (1997). Modeling teleconnections between the North Atlantic and Pacific during the Younger Dryas. Nature 387, 384-387.

Minckley, T. A., and Whitlock, C. (2000). Spatial variation of modern pollen rain in Oregon and southern Washington, USA. Review of Palaeobotany and Palynology 112, 97-123.

Mock, C. J. (1996). Climatic controls and spatial variations of precipitation in the western United States. Jounal of Climate 9, 1111-1125.

Moore, P. D., and Webb, J. A. (1978). "An Illustrated Guide to Pollen Analysis." Wiley, New York.

Overpeck, J. T., Webb, T., III, and Prentice, I. C. (1985). Quantitative interpretation of fossil pollen spectra: Dissimilarity coefficients and the method of modern analogs. Quaternary Research 23, 87-108.

Pellat, M. G., Mathewes, R. W., and Walker, I. R. (1997). Pollen analysis and ordination of lake sediment-surface samples from coastal British Columbia, Canada. Canadian Journal of Botany 75, 799-814.

Peteet, D., Del Genio, A., and Lo, K. (1997). Sensitivity of northern hemisphere air temperatures and snow expansion to North Pacific sea surface temperatures in the Goddard Institute for Space Studies general circulation model. Journal of Geophysical Research 102, 781-791.

Raymo, M. E., Ganley, K., Carter, S., Oppo, D. W., and McManus, J. (1998). Millennial-scale climate instability during the early Pleistocene epoch. Nature 392, 699-702.

Stuiver, M., and Reimer, P. J. (1993). Extended ${ }^{14} \mathrm{C}$ data base and revised CALIB $3.0{ }^{14} \mathrm{C}$ age calibration program. Radiocarbon 35, 215-230.

Thompson, R., and Oldfield, F. (1986). "Environmental Magnetism.” Allen \& Unwin, London.

Thompson, R. S., Whitlock, C., Bartlein, P. J., Harrison, S. P., and Spaulding, W.G. (1993). Climatic changes in the western United States since 18,000 yr B.P. In "Global Climates since the Last Glacial Maximum" (H. E. Wright, J. E. Kutzbach, W. F. Ruddiman, F. A. Street-Perrott, T. Webb III, and P. J. Bartlein, Eds.), pp. 468-513. University of Minn. Press, Minneapolis.

Thompson, R. S., Anderson, K. H., and Bartlein, P. J. (1999). "Atlas of relations between climatic parameters and distributions of important trees and shrubs in North America; introduction and conifers." U.S. Geological Survey Professional Paper 1650-A. U.S. Geological Survey, Reston, VA.

Warner, B. G., Clague, J. J., and Mathewes, R. W. (1984). Geology and paleoecology of a Mid-Wisconsin peat from the Queen Charlotte Islands, British Columbia, Canada. Quaternary Research 21, 337-350.

Whitlock, C., and Bartlein, P. J. (1997). Vegetation and climate change in northwest America during the past $125 \mathrm{kyr}$. Nature 388, 57-61.

Whitlock, C., and Grigg, L. D. (1999). Paleoecological evidence of Milankovitch and Sub-Milankovitch climate variations in the western U.S. during the late Quaternary. In "Mechanisms of Global Climate Change at Millennial Time Scales." (R. S. Webb, P. U. Clark, and L. D. Keigwin, Eds.), pp. 227-241. American Geophys. Union, Washington DC.

Worona, M. A., and Whitlock, C. (1995). Late-Quaternary vegetation and climate history near Little Lake, central Coast Range, Oregon. Geological Society of America Bulletin 107, 867-876.

Wright, H. E. J., Mann, D. H., and Glaser, P. H. (1983). Piston cores for peat and lake sediments. Ecology 65, 657-659. 